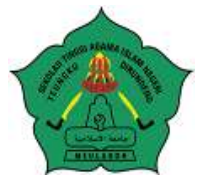

AT-TASYRI' Jurnal Ilmiah Prodi Muamalah

P-ISSN: 2085-2541, E-ISSN: 2715-7865

Volume 12, Nomor 1, Juni 2020

https://ejournal.staindirundeng.ac.id/index.php/Tasyri

\title{
MENYELESAIKAN PERMASALAHAN QANUN JINAYAT ACEH
}

\author{
Heri Maslijar \\ Anggota Peneliti Lembaga Kajian Konstitusi Indonesia (LKKI) UIN AR-RANIRY \\ maslijarmovic@gmail.com
}

\begin{abstract}
Abstrak
Meskipun belum sepenuhnya memuat sanksi hudud, penolakan terhadap qanun jinayat masih terus berlanjut hingga saat ini. Beberapa LSM seperti Solidaritas Perempuan, Institute Criminal Justice Reform (ICJR), LBH Jakarta, YLBHI, dan Kontras, terus melakukan upaya agar qanun jinayat Aceh dapat ditinjau ulang karena bertentangan dengan konstitusi Indonesia UUD 1945 terutamajināyah yang memuat 'uqūbat hudūd berupa cambuk. Disisi lain, pemerintah Aceh melalui Dinas Syariat Islam memunculkan wacana agar hukuman mati bisa diterapkan di Aceh.Wacana tersebut mengindikasikan bahwa ada serangkaian upaya agar sanksi di dalam qanun jinayat dapat menyuntuh 'uqūbat hudūd secara menyeluruh. Tulisan ini membahas pertarungan dua wacana diatasuntuk menyelesaikan serangkaian persoalan terhadap qanun jinayat Aceh. Apakah benar qanun jinayat tidak konstitusional seperti yang disuarakan, dan apakah mungkin qanun jinayat Aceh dapat memuat sanksi hudud secara menyeluruh, termasuk mencantumkan hukuman mati didalamnya sesuai kaidah fiqh jinayat.
\end{abstract}

Kata kunci: Qanun Jinayat, Aceh, Syariat Islam, 'uqūbat ḥudūd

\begin{abstract}
Although it has not yet fully contained hudud sanctions, the rejection of the Jinayat Qanun still continues to the present. Some NGOS such as women solidarity, Institute Criminal Justice Reform (ICJR), LBH Jakarta, YLBHI, and contrast, continue to make efforts to make the Qanun Jinayat Aceh can be reviewed because it contradicts the Indonesian constitution UUD 1945 especially Jināyah which contains 'Uqübat hudüd in the form of whip. On the other hand, the ACEH government through the Islamic Department gave rise to the discourse so that the death penalty could be applied in ACEH. The discourse indicates that there is a series of attempts to sanction in the Qanun Jinayat can insure 'Uqübat hudüd thoroughly. This article discusses the Battle of two discourse above to solve a series of issues against the ACEH Jinayat Qanun. Is it true Qanun Jinayat unconstitutional as is voiced, whether it is possible Qanun Jinayat contain death penalty until it contains the entire hudud article according to Fiqh Jinayat rules.
\end{abstract}

Keywords: Qanun Jinayat, Aceh, Islamic Law, 'uqūbat ḥudūd 


\section{A. Pendahuluan}

Hadirnya UU Nomor. 11 Tahun 2006 tentang Pemerintahan Aceh membuka babak baru dalam pelaksanaan syariat Islam di Aceh. Pasalnya UU Nomor. 11 Tahun 2006 (selanjutnya disebut UUPA) memberikan kewenangan yang sangat luas bagi pemerintah Aceh untuk dapat menciptakan regulasiregulasi mengenai syariat Islam. Adapun ketentuan yang menyebutkan mengenai pelaksanaan syariat Islam dalam undangundang tersebut tercantum pada pasal 125, yang berbunyi:

(1) Syariat Islam yang dilaksanakan di Aceh meliputi aqidah, syariah, dan akhlak.

(2) Syariat Islam sebagaimana yang di maksud pada ayat (1) meliputi: Ibadah, ahwal syakshiyah (hukum keluarga), muamalah (hukum perdata), jinayat (hukum pidana), qadha' (peradilan), tarbiyah (pendidikan), dakwah, syiar dan pembelaan islam.

(3) Ketentuan lebih lanjut mengenai pelaksanaan syariat islam pada ayat (1) diatur dalam qanun Aceh.

Bedasarkan ketentuan UUPA, pemberian kewenangan dalam pelaksanaan syari'at Islam di Provinsi Aceh ditindaklanjuti oleh eksekutif dan legislatif dengan menyusun qanun. Pada tahun 2014, Dewan Perwakilan Rakyat Aceh (DPRA) bersama pihak eksekutif berhasil menghasilkan Qanun Aceh Nomor. 6 Tahun 2014 tentang Hukum Jinayat dan Qanun Nomor. 7 Tahun 2013 tentang Hukum Acara Jinayat. Pasca disahkan, qanun jinayat berhasil mencuri perhatian nasional hingga internasional. Pro-kontra terhadap qanun jinayatpun mulai menguat. Hingga pada taraf tertentu, pro dan kontra tersebut mengarah pada penolakan secara penuh terhadap qanun jinayat Aceh.

Penolakan tesebut muncul dari berbagai LSM seperti Solidaritas Perempuan, Institute Criminal Justice Reform (ICJR), LBH Jakarta, YLBHI, Kontras, Serikat Jurnalis untuk Keberagaman (SEJUK), Aliansi Nasional Bhineka Tunggal Ika (ANBTI) Solidaritas Perempuan Bungoeng Jeumpa Aceh, AJI Aceh, dan LBH Aceh. ${ }^{1}$ Bahkan ICJR dan Solidaritas Perempuan telah mengajukan gugatan ke Mahkamah Agung agar dilakukan judicial review terhadap qanun jinayat karena dianggap melanggar Konstitusi UUD 1945 yang menjunjung tinggi Hak Asasi Manusia.

Salah satu materi yang ditolak dalam qanun jinayat Aceh adalah mengenai sanksi hudūd berupa cambuk, karena dianggap bertentangan dengan UUD 1945 pasal 28G ayat 1 yang berbunyi:

(1) Setiap orang berhak atas perlindungan diri pribadi, keluarga, kehormatan, martabat, dan harta benda yang di bawah kekuasaannya, serta berhak atas rasa aman dan perlindungan dari ancaman ketakutan untuk berbuat atau tidak berbuat sesuatu yang merupakan hak asasi.

(2) Setiap orang berhak untuk bebas dari penyiksaan atau perlakuan yang merendahkan derajat martabat manusia dan berhak memperoleh suaka politik dari negara lain.

Jadi bedasarkan ketentuan UUD 1945 pasal 28G ayat 1, beberapa LSM tersebut berpendapat bahwa qanun jinayat Aceh perlu ditinjau ulang karena bertentangan dengan undang-undang tertinggi Indonesia (konstitusi). Qanun jinayat yang memuat

\footnotetext{
${ }^{1}$ Selengkapnya baca di, https://nasional.kompas.com/read/2016/10/23/23340501/setahun.diberlakukan. qanun.jināyah.Aceh.diminta.dikaji.ulang.
} 
uqūbat hudūd seperti cambuk tidak manusiawi dan merendahkan martabat manusia.

Gencarnya arus penolakan terhadap qanun jinayat Aceh- disisi lain pemerintah Aceh melemparkan wacana untuk menambahkan pasal baru didalam qanun jinayat, yakni mengenai hukuman mati (qisas).

Seperti yang telah dilansir oleh beberapa media nasional, pemerintah Aceh melalui dinas Syari'at Islam menyampaikan wacana untuk menerapkan hukum qisas(pancung) dalam sanksi pidana. Wacana tersebut langsung ditanggapi oleh Menteri Hukum dan HAM Yasonna Laoly. Yasonna mengatakan bahwa hukuman mati kepada pelaku kejahatan tidak bisa diterapkan jika hanya diatur dengan peraturan daerah Provinsi Aceh, menurutnya aturan tersebut harus diterapkan dengan undang-undang. ${ }^{2}$

Perlu diketahui bahwa saat ini Sanksi ('uqūbat) yang terdapat dalam qanun jinayat Aceh masih didominasi dengan 'uqūbat ta'zīr sedangkan 'uqūbatdengan kategori hudud hanya dikenakan pada jarimah zina, jarīmahqażaf dan jarimahkhamar. Padahal di dalam hukum pidana Islam (fiqh jinayat) diatur beberapa jarimah lain yang diancam dengan sanksi hudud seperti mencuri, memberontak, murtad, dan membunuh.

Meskipun belum sepenuhnya memuat sanksi hudud, polemik mengenai qanun jinayat masih terus berlanjut. Beberapa LSM seperti yang penulis sebutkan di atas masih terus vokal menyuarakan agar qanun jinayat Aceh ditinjau ulang karena bertentangan dengan konstitusi Indonesia UUD 1945 terutama jināyat yang memuat 'uqūbat ḩudūd berupa cambuk. Di sisi lain, pemerintah Aceh melalui Dinas Syariat Islam memunculkan wacana agar hukuman mati bisa diterapkan di Aceh. Wacana tersebut mengindikasikan bahwa ada serangkaian upaya agar sanksi di dalam qanun jinayat dapat menyuntuh 'uqūbat hudūd secara menyeluruh. Oleh karena itu, penelitian ini dilakukan lebih lanjut untuk melihat bagaimana konstitusionalitas qanun jinayah Aceh. Apakah benar qanun jinayat Aceh bertentangan dengan HAM UUD 1945, dan apakah qanun jinayat Aceh dapat memuat sanksi hudud secara menyeluruh, termasuk memuat hukuman mati di dalamnya.

\section{B. KAJIAN PUSATAKA}

Kajian mengenai qanun jinayat Aceh sudah cukup banyak dibahas, diantaranya adalah tesis tesis dari Khairil Akbar yang berjudul "Relevansi Prinsip Pemidanaan Islam Terhadap Sila Ketuhanan Yang Maha Esa (Studi Terhadap Qanun Aceh Nomor 6 Tahun 2014 Tentang Hukum Jinayat)". ${ }^{3}$ Selanjutnya tulisan dari Husni Mubarak A. Latief dengan judul "Disonansi Qanun Syari'at Islam Dalam Bingkai Konstitusi Hukum Indonesia: Aceh Sebagai Studi Kasus". ${ }^{4}$ Tulisan dari Zaki Ulya "Dinzamika Penerapan Hukum Jināyah Sebagai Wujud Rekontruksi Syari'atIslam di Aceh" juga membahas hal yang serupa, dan masih banyak kajian lain mengenai qanun jinayat Aceh. Tulisan ini sendiri merupakan ikhtiar penulis untuk mencoba mengisi kekosongan dari beberapa tulisan sebelumnya dengan cara melihat tingkat konstitusionalitas dan peluang

\footnotetext{
${ }^{2}$ Baca selengkapnya di http://Aceh.tribunnews.com/2018/03/16/wacana-hukuman-pancung-di-Aceh-prodan-kontra-warganet-hingga-ditentang-pemerintah-pusat.

${ }^{3}$ KhairilAkbar, Relevansi Prinsip Pemidanaan Islam Terhadap Sila Ketuhanan Yang Maha Esa (Studi Terhadap Qanun Aceh Nomor 6 Tahun 2014 Tentang Hukum Jinayah), (Yogyakarta : Pasca Sarjana UII, 2017).

${ }^{4}$ Husni Mubarak A. Latief, "Disonansi Qanun Syari' at Islam Dalam Bingkai Konstitusi Hukum Indonesia : Aceh Sebagai Studi Kasus", Annual International Conference on Islamic Studies (AICIS XII).
} 
positivisasi jinayah hudud secara menyeluruh di Aceh.

\section{METODE PENELITIAN}

Jenis penelitian ini merupakan penelitian hukum normatif. Jenis penelitian hukum normatif ini akan melihat taraf sinkronisasi UUD 1945 sebagai konstitusi Indonesia dengan sanksi hudud yang terdapat di dalam qanun jinayat Aceh. Pendekatan penelitian ini menggunakan pendekatan perundang-undangan (statute approach). Pendekatan perundang-undangan ini akan mengkaji secara sistematis sanksi hudud yang terdapat di dalam qanun jinayat kemudian dilihat kesesuaiannya dengan konstitusi Indonesia, sekaligus melihat peluang positivisasi jināyah ḥudūd secara menyeluruh di Aceh.

\section{Hasil dan Pembahasan}

\section{Qanun Jinayat Aceh}

Secara yuridis, qanun jinayat Aceh merupakan turunan dari UUPA dan dikuatkan pula dengan qanun No 8 Tahun 2014 tentang pokok-pokok Syari'at Islam. Qanun jinayat adalah qanun yang mengatur tentang jarimah (delik/tindak pidana) pelaku jarimah, dan 'uqūbat (sanksi/hukuman). Qanun jinayat sering disebut juga hukum pidana Islam (hukum jināyah) karena fokusnya mengatur pada masalah pelaku tindak pidana, perbuatan pidana (jarīmah), dan hukuman ('uqūbat). ${ }^{5}$

Qanun jinayat memuat asas personalitas dan teritorial dalam mengatur subyek hukum.
Berdasarkan asas personalitas, pelaksanaan qanun jinayat hanya bagi subyek hukum yang beragama Islam, sedangkan bagi non muslim tunduk secara sukarela atau tidak bila melakukan jarimah berbarengan dengan seorang muslim atau lebih. Jika ketentuan pidana tidak diatur didalam KUHP maka tunduk secara penuh. Bedasarkan asas teritorial berlakunya qanun jinayat hanya di wilayah hukum provinsi Aceh.Adapun materi muatan qanun sendiri terdiri atas 10 (sepuluh) bab dan 75 (tujuh puluh lima) pasal.

Qanun Jinayat menganut asas keislaman, legalitas, keadilan dan keseimbangan, kemaslahatan, perlindungan hak asasi manusia, dan asas pembelajaran kepada masyarakat (tadabbur).

Qanun jinayat Aceh merupakan qanun yang memiliki kekhususan dan keistimewaan tersendiri jika dibandingkan dengan qanun Aceh yang mengatur tentang penyelengara pemerintahan. Menurut Syahrizal Abbas, qanun Aceh yang berkaitan dengan penyelenggara pemerintahan sama kedudukannya dengan perda pada umumnya, dan dapat dibatalkan dengan Peraturan Pemerintah (PP). tapi tidak demikian dengan qanun jinayat, ada perbedaan yang signifikan. Jika qanun Aceh mengenai pemerintahan dapat dibatalkan dengan PP,maka qanun Aceh mengenai Syari'at Islam-qanun jinayathanya dapat dibatalkan melalui prosedur judicial review ${ }^{6}$ di Mahkamah Agung. ${ }^{7}$

Adapun kekhususan dan keistimewaan lain dari qanun jinayat yaitu mengenai sanksi

\footnotetext{
${ }^{5}$ Noviandy (ed.), Perempuan dan Hak Asasi Manusia ; Narasi Agama dalam Imajinasi Negara Bangsa di Aceh, (Malang : PUSAM UMM, 2018), hal. 115.

${ }^{6}$ Judicial Review (hak uji materil) adalah wewenang untuk menyelidiki, menilai, apakah suatu peraturan perundnag-undangan isinya sesuai atau bertentangan dengan peraturan yang lebih tinggi derajatnya, serta apakah suatu kekuasaan tertentu (verodenende macht) berhak mengeluarkan peraturan tertentu. Hak uji materil tersebut melekat pada Mahkamah Agung sebagai lembaga yudikatif untuk menyatakan sah atau tidaknya suatu peraturan perundang-undangan dengan ukuran konstitusi, dan apabila sesuai maka peraturan tersebut boleh dijalankan, apabila tidak maka peraturan tersebut dibatalkan. Selengkapnya lihat ; Siti Fatimah, Praktik Judicial Review di Indonesia : Sebuah Pengantar, (Yogyakarta: Pilar Media, 2005), hal. 17-18.

${ }^{7}$ Syahrizal Abbas,Maqasidh Al-Syariah Dalam Hukum Jinayah Aceh, (Banda Aceh: Dinas Syari'at Islam Aceh, 2015), hal. 30.
} 
yang ada di dalam qanun dapat melebihi sanksi yang disebutkan dalam UndangUndang Nomor. 12 Tahun 2011 mengenai pembentukan peraruran daerah. Jika didalam Undang-Undang Nomor 12 Tahun 2011 menyebutkan bahwa sanksi pidana didalam perda tingkat provinsi dan kabupaten/kota, hanya boleh memuat ancaman pidana paling lama 6 bulan kurungan, dan denda paling banyak 50.000.000 (lima puluh juta rupiah), maka qanun jinayat Aceh dikecualikan dari ketentuan tersebut.

Pengecualian tersebut langsung disebutkan didalam UUPA pada pasal 241 ayat 1-4. Dalam pasal tersebut terlihat jelas bahwa pengecualian dalam ketentuan materi qanun jinayat mengenai sanksi, boleh melebihi sanksi yang disebutkan dalam UU No. 12 / 2011.

Hal lain yang membuat qanun jinayat dapat memuat sanksi yang melebihi ketentuan UU No. 12/ 2011 dikarenakan qanun jinayat sendiri merupakan perintah langsung dari undang-undang dan memiliki hirarki (turunan) dari beberapa undang-undang, ${ }^{8}$ antara lain:

1. Undang-undang Dasar Negara Kesatuan Republik Indonesia Tahun 1945. Undang-undang dasar sebagai konstitusi di Indonesia mengatur secara jelas tentang pemerintahan daerah, yang diberikan hak untuk menetapkan peraturan daerah, hal ini disebutkan dalam Pasal 18 ayat 6 .

2. Undang-Undang Nomor 24 Tahun 1956 tentang Pembentukan Daerah Otonom
Provinsi Atjeh dan Perubahan Peraturan Pembentukan Provinsi Sumatera Utara.

3. Undang-Undang Nomor 44 Tahun 1999 tentang Penyelenggaraan Keistimewaan Provinsi Daerah Istimewa Aceh. ${ }^{9}$

4. Undang-undang Nomor 18 Tahun 2001 mengenai otonomi khusus bagi provinsi Aceh.

5. Undang-Undang Nomor 11 Tahun 2006 tentang Pemerintahan Aceh. Pasal 125 yang menyatakam Hukum Pidana (Hukum Jinayah) merupakan bagian dari Syari'at Islam yang dilaksanakan di Aceh.

Karena itu, berdasarkan hirarki undangundang di atas, maka landasan yuridis berlakunya qanun jinayat Aceh konstitusional. Menurut Dr. EMK Elidar, qanun jinayat merupakan qanun yang sangat konstitusional karena memiliki hirarki perundang-undangan yang sangat kuat. pasalpasal mengenai 'uqūbat di dalam qanun dapat dikecualikan, dan bahkan boleh melebihi sanksi yang diatur di dalam Perda. Hal tersebut merupakan wujud kekhususan yang ada didalam tubuh qanun jinayat dan tercatat langsung di dalam UUPA.

Bahkan sangat memungkinan dengan kekhususan tersebut Qanun Jinayat Aceh memuat pasal pidana yang melampaui KUHP Indonesia. ${ }^{10}$

\section{Konstitusionalitas Jinayah Hudud}

Konstitusi Indonesia menentukan bahwa kebebasan beragama merupakan hak yang dimiliki oleh setiap warga negara. Agama bukanlah pemberian dari negara atau

\footnotetext{
${ }^{8}$ Pendapat Rusjdi Ali Muhammad, dikutip dari Disertasi Mudzakir, selengkapnya lihat : Muzakkir, Adopsi dan Aplikasi Hukum Jinayah Melalui Qanun Aceh (Studi Terhadap Qanun Nomor 6 Tahun 2014), (Medan : Pasca Sarjana USU, 2017), hal. 243.

${ }^{9}$ Lihat: Undang-Undang Nomor 44 Tahun 1999, tentang Keistimewaan Aceh, pasal 1 ayat 10 yang menyebutkan bahwa Syari'at Islam tuntunan di seluruh aspek kehidupan dan pasal 3 ayat 2 yang menyebutkan bahwa keistimewaan yang diberikan untuk melaksanakan kehidupan beragama.

${ }^{10}$ Wawancara dengan Kepala Dinas Syari'at Islam Aceh EMK Elidar, Banda Aceh, pada tanggal 7 Agustus 2018 .
} 
pemberian dari golongan tertentu. Agama dan kepercayaan kepada Tuhan YME itu bedasarkan keyakinan, hingga keyakinan tersebut tidak bisa dipaksakan pada tiap-tiap manusia. Keyakinan kepada Tuhan merupakan kesadaran batin yang luhur pada setiap jiwa manusia, sehingga seseorang yang meyakini adanya Tuhan memiliki konsekuensi untuk menjalankan serangkaian ritual dan peribadatan kepada Tuhannya sebagaimana diatur dalam petunjuk agamanya masing-masing.

Dalam UUD 1945 sebagaimana yang telah dijelaskan di atas, bahwa menjalankan peribadatan menurut agamanyamasingmasing adalah jaminan hak yang diatur di dalam UUD 1945 pasal 28E dan 29. Selanjutnya ditegaskan pula dalam Pasal 2 Undang-Undang Nomor 39 Tahun 1999 tentang HAM yang menyebutkan bahwa "Negara Republik Indonesia mengakui dan menjunjung tinggi HAM dan kebebasan dasar manusia sebagai hak yang secara kodrati melekat pada dan tidak terpisahkan dari manusia yang harus dilindungi, dihormati dan ditegakkan demi peningkatan martabat kemanusiaan, kesejahteraan, kebahagiaan dan kecerdasan serta keadilan".

Pasal 4 Undang-Undang Nomor 39 Tahun 1999 menyatakan bahwa: "hak untuk hidup, hak untuk tidak disiksa, hak kebebasan pribadi, pikiran dan hati nurani, hak beragama, hak untuk tidak diperbudak, hak untuk diakui sebagai pribadi dan persamaan dihadapan hukum, dan hak untuk tidak dituntut atas dasar hukum yang berlaku surut adalah HAM yang tidak dapat dikurangi dalam keadaan apapun dan oleh siapa pun".

HAM dalam UUD 1945 dapat diklasifikasikan menjadi empat kelompok, yaitu hak sipil dan politik, hak ekonomi, sosial, dan budaya, hak atas pembangunan dan hak khusus lain, serta tanggung jawab negara dan kewajiban asasi manusia. ${ }^{11}$ Selain itu, terdapat hak yang dikategorikan sebagai hak yang tidak dapat dikurangi dalam keadaan apapun (nonderogable rights) yang meliputi hak untuk hidup, hak untuk tidak disiksa, hak kemerdekaan pikiran dan hati nurani, hak beragama, hak untuk tidak diperbudak, hak untuk diakui sebagai pribadi di hadapan hukum, dan hak untuk tidak dituntut atas dasar yang berlaku surut. ${ }^{12}$

Muatan HAM dalam UUD 1945 mengenai hak privasi yang tidak dapat ditambah dan dikurang (non-derogable rights) tercantum di dalam pasal 28 I ayat 1 , yang meiliputi hak-hak yang telah disebutkan di atas. Mengenai penjelasan selanjutnya di atur di dalam UU No. 39 Tahun 1999 tentang Hak Asasi Manusia pasal 4, menjelaskan yang dimaksud dalam "keadaan apapun" ialah menyangkut seluruh keadaan yakni keadaan perang, sengketa bersenjata, dan atau keadaan darurat. jadi hak non-derogable merupakan hak dasar yang harus dijamin dan dilindungi dalam pelaksanaanya, karena itu muatan konstitusi UUD 1945 memuat dan mengatur mengenai hak non-derogeble tersebut.13

Hak menjalankan dan memeluk agama masing-masing merupakan hak yang dilindungi didalam konstitusi Indonesia, dan termasuk dalam kategori non-derogable

\footnotetext{
${ }^{11}$ Selengkapnya lihat UUD 1945 BAB XA pasal 28A sampai dengan 28I,atau lihatbuku“Konstitusi dan Konstitusionalisme” oleh Jimly Asshiddiqie, dalam buku tersebut telah dirangkum dan dikategorikan secara jelas mengenai hak dan kewajiban asasi manusia dari hak sipil sampai tanggung jawab negara dan kewajiban asasi manusia. Selengkapnya, Jimly Asshiddiqie, Konstitusi dan Konstitusionalisme Indonesia : 82-91.

${ }^{12}$ UUD 1945 BAB XA pasal 28I Ayat 1. Selain hak yang tidak dapat dikurangi dalam keadaan apapun (nonderogable rights), muatan HAM Indonesiajuga mengenal derogable rights atau hak-hak yang masih dapat dikurangi atau dibatasi pemenuhannya oleh negara dalam keadaan tertentu.

${ }^{13}$ Lihat UU No. 39 Tahun 1999 tentang Hak Asasi Manusia pasal 4.
} 
(tidak dapat dikurangi dalam keadaan apapun). Mengenai hal tersebut diatur didalam pasal 28E ayat 1 UUD 1945 yang menyatakan bahwa Setiap orang bebas memeluk agama dan beribadat menurut agamanya, memilih pendidikan dan pengajaran, memilih pekerjaan, memilih kewarganegaraan, memilih tempat tinggal di wilayah negara dan meninggalkannya, serta berhak kembali." Pasal 29 ayat 2 juga menyatakan, "Negara menjamin kemerdekaan tiap-tiap penduduk untuk memeluk agamanya masing-masing dan untuk beribadat menurut agamanya dan kepercayaannya itu".

UUD Tahun 1945, menentukan bahwa hak kebebasan beragama bukan pemberian negara atau bukan pemberian golongan. Agama dan kepercayaan terhadap Tuhan Yang Maha Esa itu berdasarkan keyakinan, hingga tidak dapat dipaksakan dan memang agama dan kepercayaan terhadap Tuhan Yang Maha Esa itu sendiri tidak memaksakan setiap manusia untuk memeluk dan menganutnya. ${ }^{14}$

Islam merupakan agama yang kompleks, tidak hanya mengatur mengenai hubungan antara manusia dan Tuhan (privat) tapi juga mengatur mengenai hubungan manusia dengan manusia lainnya (publik). Dalam mengatur kedua urusan tersebut Allah SWT menurunkan Al-Quran dan Sunnah sebagai sumber utama untuk dipedomani.

Al-Quran dan Hadis tersebut memuat serangkaian hukum mengenai tata cara berkehidupan yang menyeluruh bagi umat muslim, dan hukum yang dimaksud sering disebut dengan syari'at. Syari'at terbagi kedalam dua dimensi yakni; ibadah dan muamalah. Ibadah sendiri meliputi shalat, puasa, zakat, dan haji. Sedangkan syari'at sendiri meliputi hukum keluraga, hukum perdata, hukum pidana, hukum politik- ketatanegaraan, dan lain-lain. Karena itu, bagi umat muslim menjalankan dan melaksanakan syari'at merupakan bagian dalam melaksanakan perintah agama sebagaimana yang dijamin dalam UUD 1945.

Dimensi syari'at tersebut ada yang memerlukan kekuasaan negara dalam pelaksanaanya dan ada yang dapat dilaksanakan tanpa kekuasaan negara. misalnya dalam bidang aqidah dan pengalaman ibadah, tak perlu adanya kekuasaan negara, akan tetapi dalam bidang pidana, tentu memerlukan kekuasaan negara dalam penegakkannya. Tanpa adanya kekuasaan negera dimensi syari'at tersebut tidak dapat dilaksanakan. ${ }^{15}$

Hudūd merupakan salah satu jenis sanksi yang terdapat dalam hukum pidana Islam dan merupakan dimensi dari syari'at. Dimensi tersebut perlu terlebih dahulu diatur oleh negara agar dapat dilaksanakan dan dijalankan, karena dimensi hudud merupakan ranah publik yang mengatur hubungan manusia dengan manusia lain, bukan ranah privat. Dalam konteks hukum pidana Indonesia, memasukkan pidana hudud kedalam KUHP atau menerapkan hukum pidana Islam secara harfiah perlu adanya pengkajian teliti dan serius. Meskipun konstitusi menjamin setiap warga negara untuk menjalankanserangkaian titah agama, akan tetapi dalam hal yang menyentuh keterlibatan negara perlu adanya aturan lebih lanjut mengenai hal yang dimaksud.

Menurut Dr. Hamid Chalid salah seorang praktisi hukum UI, berpendapat bahwa jika ditinjau dari konstitusi, gagasan hukum pidana Islam sangat relevan dalam konteks negara hukum Indonesia. Hal tersebut dikarenakan Indonesia adalah negara yang berketuhanan, sebagaimana tercantum dalam

\footnotetext{
${ }^{14}$ Sodikin, Hukum dan Kebebasan Beragama, Jurnal Cita Hukum, Vol. 1 No. 2, 2013, hal. 180.

${ }^{15}$ Syahrizal Abbas,Maqasidh Al-Syariah Dalam Hukum Jinayah Aceh :18.
} 
pancasila. Kemudian ditambah lagi pengakuan mengenai hak beragama dan hak untuk menjalankan titah agama tersebut di dalam UUD 1945. Jadi peluang hukum pidana Islam dalam ranah hukum nasional terbuka lebar. Menurutnya, gagasan hukum pidana Islam yang memuat sanksi hudud tidak perlu dipertentangkan dengan konstitusi karena problem sebenarnya murni ada di political will. ${ }^{16}$

Sedangkan menurut Mahrus Munajat dalam konteks hukum pidana Islam di Indonesia, jenis-jenis hukuman yang telah ditetapkan didalam Al-Quran dan Hadist Nabi tidak harus diterapkan secara harfiah. Tetapi jenis dan bentuk hukuman apapun dapat dibenarkan asalkan sesuai dengan tujuan pensyari'atan hukum pidana Islam. ${ }^{17}$

Oleh karena itu perumusan hukuman yang sejalan dengan kondisi saat ini juga dapat dibenarkan. Jenis hukuman yang terdapat dalam Al-Quran dan Hadis hanya dipandang sebagai batas maksimal yang diterapkan manakala bentuk hukuman lain tidak dapat mewujudkan tujuan hukuman tersebut. ${ }^{18}$

Dalam konteks Aceh, pelaksanaan hukum pidana Islam yang telah dirumuskan kedalam qanun jinayat merupakan perintah langsung dari undang-undang. Selain itu, pelaksanaan qanun jinayat Aceh juga sejalan dengan rumusan UUD 1945 mengenai penyelenggaraan kehidupan beragama. Jadi, jika selama ini ada beberapa pihak yang menganggap bahwa qanun jinayat tidak konstitusional dan melanggar HAM, itu merupakan anggapan yang keliru. Justru hadirnya qanun jinayat di tengah-tengah masyarakat Aceh yang mayoritas beragama Islam, merupakan bagian dari pelaksanaan HAM itu sendiri, yakni hak untuk melaksanakan kehidupan beragama dan menjalankan titah agama sebagaimana yang telah dijamin didalam UUD 1945.

$$
\text { UUD } 1945 \text { pasal } 29 \text { ayat (2) }
$$

menyebutkan bahwa; "Negara menjamin kemerdekaan tiap-tiap penduduk untuk memeluk agamanya masing-masing dan untuk beribadat menurut agamanya dan kepercayaannya itu". Menurut Hazairin, kata "beribadat" merupakan kelanjutan dari jaminan negara bagi tiap-tiap penduduk untuk memeluk agama, seperti dimaksudkan dalam pasal 29 ayat (2) tersebut. Tak bisa dipahami makna lain, selain pengertian menjalankan syari'at (hukum) agama. Jadi menurut Hazairin, bedasarkan UUD 1945 negara berkewajiban untuk melaksanakan tugasnya untuk melindungi dan mengakui hukum yang terdapat didalam berbagai agama di Indonesia, misal syari'at Islam untuk orang Islam dan hukum kristen untuk orang kristen dan sebagainya. ${ }^{19}$ Hanya saja pelaksanaan hukum-hukum agama tersebut perlu diatur selanjutnya dalam Undang-undang, sebagaimana yang diatur dalam pasal $28 \mathrm{~J}$ UUD 1945.

Pelaksanaanqanun jinayat Aceh juga merupakan bagian dari menjalankan hak yang sifatnya non-derogable (tidak dapat dikurangi dalam keadaan apapun), hak-hak tersebut mencakup hak untuk beragama bagi

\footnotetext{
${ }^{16}$ Pendapat tersebut disampaikan beliau pada salah satu sesi wawancara dengan redaksi hukumonline.com pada tanggal 17 Oktober 2017, selengkapnya lihat https://www.hukumonline.com/berita/baca/lt59e5b3502e8dd/ melihat-kembali-tempat-hukum-pidana-islam-dalam-sistem-hukum-nasional.

${ }^{17}$ Menurut Makhrus Munajat tujuan dari hukum pidana Islam adalah untuk memelihara lima hal yakni; agama, jiwa, akal, kehormatan, keturanan, dan harta, atau sering disebut juga dengan hifz al-khamsah sebagaimana tujuan dari syari'at (maqasidh al-syari'ah).

${ }^{18}$ Makhrus Munajat, Hukum Pidana Islam di Indonesia, (Yogyakarta : Sukses Offset, 2008), hal. 274.

${ }^{19}$ Abdul Gani Isa, FormalisasiSyari'at Islam di Aceh (PendekatanAdat, Budaya, danHukum), (Banda Aceh: Yayasan Pena, 2013), hal. 327.
} 
pemeluknya sebagaimana diatur dalam UUD 1945 pasal 28I ayat (1) dan 28E ayat (1). Penjelasan selanjutnya juga dikuatan oleh UU No. 39/ 1999 tentang HAM tepatnya pasal 22 yang menyatakan: (1) "Setiap orang bebas memeluk agamanya masing-masing dan untuk beribadat menurut agamanya dan kepercayaannya itu". Dalam hal ini kemerdekaan penduduk untuk memeluk agamanya dan melakukan serangkaian peribadatan sesuai ketentuan agama, negara bertanggung jawab untuk melindungi, menghormati, dan menegakkan hak asasi tersebut. Jadi pemerintah wajib dan bertanggungjawab menghormati, melindungi, menegakkandan memajukan hak beragama di Republik Indonesia. Maka dalam konteks Qanun Jinayat Aceh, negara (pemerintah) bukan hanya berperan memfasilitasi dan melindungi dalam pelaksanaannya, tapi juga ikut terlibat dalam mendesain formulasi-formulasi dan muatan hukum dalam qanun jinayat melalui proses legislasi misalnya, dan hal tersebut merupakan kewajiban konstitusional yang harus dilakukan oleh pemerintah. ${ }^{20}$

Selama ini ada beberapa lembaga LSM yang menyatakan bahwa Qanun Jinayat yang memuat sanksi hudud didalmnya bertentangan dengan UUD 1945 dan konvensi HAM International. Sanksi hudūd berupa cambuk di dalam Qanun Jinayat dianggap merupakan hukum yang kejam dan diskriminatif terhadap nilai-nilai kemanusiaan.

Jika ditinjau dari aspek HAM versi Barat, kelihatan seolah-olah sanksi hudud didalam qanun jinayat sangat bertentangan prinsip kemanusiaan. Kekliruan ini muncul karena melihat sanksi hudud dalam qanun jinayat hanya pada satu sisi saja, tanpa melihat sisi yang lain. Padahal bagi umat Islam, hukuman hudûd diyakini sebagai sesuatu yangpatut dan akan mencapai ke-mashlahatan individual dan sosial yang muncul dari aspek retribusi dan deterrence, karena ketentuan hukuman tersebut adalah ketetapan Tuhan.

Pada hakikatnya, tidak ada sanksi di dunia ini yang tidak melanggar HAM. Karena salah satutujuan dari sanksi itu sendiri adalah memberikan nestapa dengan cara membatasi hak. Misalnya sanksi penjara yang membatasi hak merdeka/bebas, hukuman mati yang mengambil hak hidup, kerja sosial yang juga mengambil hak merdeka seseorang, dan sebagainya. Jadi sangat diskriminatif jika mengatakan hanya sanksi hudud yang kejam dan melanggar HAM, padahal esensi dari sanksi itu sendri adalah untuk membatasi HAM karena ada hak orang lain yang telah dilanggar.

Pernyataan-pernyataan seperti qanun jinayat tidak konstitusional, mengabaikan nilai-nilai HAM, dan merendahkan martabat manusia, sangat tidak tepat jika ditujukan kepada sanksi hudūd yang ada di dalam materi Qanun Jinayat Aceh, karena ; Pertama, qanun jinayat merupakan qaun yang konstitusional dan sesuai dengan nilai-nilai pancasila dan UUD 1945, seperti yang telah penulis jelaskan di atas. Kedua, sanksi hudūd di dalam qanun hanya dilihat dari satu aspek saja, padahal pemidanaan hudūdmemiliki hukum acara yang sangat ketat, tidak semena-mena. Hal tersebut merupakan pertimbangan untuk menjaga nilai-nilai kemanusiaan. Di Aceh sendiri nilai-nilai islam juga sangat diterima masyarakat, jadi tidak ada yang merasa dirugikan.

Ketiga, salah satu instrumen HAM dalam Deklarasi Universal HAM yang berkaitan dengan hak kebebasan beragama Pasal 18, menyatakan bahwa "setiap orang

${ }^{20}$ Syahrizal Abbas, Maqashid Al-Syari'ah. : 17. 
berhak atas kebebasan pikiran, hati nurani dan agama; hak ini termasuk kebebasan menyatakan agama atau kepercayaannya dengan cara mengajarkannya, melakukannya, beribadat dan menepatinya, baik sendiri maupun bersama-sama dengan orang lain, dan tempat umum maupun tersendiri”. Bedasarkan deklarasi HAM universal tersebut sudah jelas bahwa, qanun jinayat merupakan bagian dari melaksanakan kebebasan beragama yang berada di wilayah Aceh.

Keempat, Qanun Jinayat Aceh lebih menekankan aspek HAM dari perspektif Islam, bukan deklarasi HAM universal PBB. terdapat perbedaan yang signifikan antara HAM PBB dengan HAM Islam yakni, HAM dalam konsep Islam merupakan anugrah dari Allah SWT, bukan pemberian dari siapapun. Sifat HAM dalam konsep Islam adalah theosentris. Tujuan dari konsep HAM Islam sendiri untuk menjaga hifdz al-khamsah seperti yang telah dijelaskan sebelumnya. Sementara deklarasi HAM universal merupakan kesepakatan manusia yang sifatnya antroposentris, karenanya dapat dirubah dicabut dan dibatalkan. Jadi hasil dari uraian diatas membuktikan bahwa tuduhantuduhan dan pernyataan negatif yang selama ini didengungkan terhadap sanksi hudūd didalam qanun jinayat sangatlah tidak tepat. ${ }^{21}$

Karena itu qanun jinayat Aceh yang saat ini memuat sanksi hudūd berupa cambuk, sangat konstitusional, dan tidak melanggar dengan konstitusi atau instrumen HAM manapun. Bahkan qanun jinayat Aceh sangat memungkinkan untuk memuat sanksi hudūd yang lain selain cambuk, karena memiliki landasan yuridis yang sangat kuat dan merupakan perintah langsung dari UndangUndang.

\section{Prospek Jinayah Hudud}

Pasca UUPA, Aceh mulai membuka ruang yang luas untuk melakukan perbincangan menganai gagasan Islamisme dan etno-nasionalis. Gagasan tersebut dibicarakan dalam salah satu ruang demokrasi-parlemen. Para elit GAM yang tadinya merupakan kombatan, kini telah ikut menjalani kehidupan yang demokratis dan mulai menduduki kursi parlemen melalui FPA (Fraksi Partai Aceh). ${ }^{22}$

UU No 11 Tahun 2006 tentang Pemerintahan Aceh sesungguhnya bukan hanya memperkukuh pelaksanaan syariat Islam di Aceh, tapi juga memperkukuh status identitas ke-Acehan (etno-nasionalisme) yang selama ini diperjuangkan oleh GAM. Akan tetapi saat GAM ingin menterjemahkan gagasan etno-nasionalism ${ }^{23}$ tersebut dalam ruang publik, malah mendapat sambutan yang kurang baik dari masyarakat Aceh. ${ }^{24}$ Bedahalnya saat para elit ingin menterjemahkan gagasan Islamisme ke dalam ruang yang sama, malah mendapat sambutan yang positif dari masyarakat Aceh. Padahal kedua gagasan itu merupakan topik utama yang selalu dibicarakan sejak awal reformasi,

${ }^{21}$ Danial, Qanun Jinayah Aceh dan Perlindungan HAM, Jurnal Kajian Hukum Islam Al-Manahij, Vol VI No.1, 2012, hal. 93.

${ }^{22}$ Partai Aceh merupakan salah satu partai politik lokal yang muncul setelah MoU Helsinki. GAM yang tadinya merupakan organisasi kombatan kini bertranformasi menjadi Partai Politik. Awalnya partai tersebut bernama Partai GAM, tapi karena diprotes oleh pihak pemerintah Indonesia maka nama partai diubah menjadi Partai Aceh.

\footnotetext{
Aceh.

${ }^{23}$ Gagasan etno-nasionalisme yang dimaksud adalah mengenai hymne Aceh, Wali Nangroe, dan Bendera

${ }^{24}$ Penolakan mengenai Wali nangroe, Hymne, dan Bendera Aceh tersebut dilakukan sangat masif oleh beberapa elemen masyarakat. Selengkapnya baca https://aceh.tribunnews.com/2017/11/01/sayembara-himneaceh-diprotes, https://www.merdeka.com/peristiwa/mahasiswa-aceh-rakyat-butuh-kesejahteraan-bukan-walinanggroe.html, http://www.tribunnews.com/topic/kontroversi-bendera-aceh.
} 
tentang apakah Aceh ingin menghendaki formalisasi hukum Syari'ah atau kemerdekaan. ${ }^{25}$

Menurut Muhammad Alkaf, ruang politik untuk syariat Islam di Aceh semakin terbuka lebar. Pasca Mou Helsinki dan lahirnya UUPA, Gagasan Islamisme (syari'at Islam) kian berada ditengah, beda halnya dengan gagasan etno-nasionalis yang semakin berada di pinggiran. Bahkan kini, produk hukum Syari'ah telah banyak lahir dan mendapat sambutan positif dari masyarakat, berbanding terbalik dengan produk hukum yang bercorak etno-nasionalis seperti, hymne, wali nangroe, dan bendera Aceh, nyaris tidak mendapat dukungan penuh dari masyarakat dan bahkan sempat memunculkan riak-riak perlawanan. Jika dilihat bedasarkan penelusuran genealogis, dapat dikatakan bahwa gagasan Islamisme dalam bentuk formalisasi syari'at Islam di Aceh telah memenangkan pertarungan narasi. ${ }^{26}$

Penelusuran genealogis $\mathrm{di}$ atas memperlihatkan bahwa ruang politik untuk syari'at Islam semakin terbuka lebar di Aceh, sehingga peluang positivisasi jināyah ḥudūd secara menyeluruh di dalam qanun jinayat juga semakin terbuka lebar. Selain didukung dengan kehendak politik pemerintah daerah yang ingin menyelesaikan Qanun Jināyah ke tahap selanjutnya, peluang positivisasi tersebut juga didukung oleh kehendak masyarakat yang ingin menerapkan syari'at Islam secara kaffah di Aceh.

Berdasarkan teori politik hukum Islam yang melihat upaya pemberlakuan hukum islam sebagai hukum yang hidup (living law) dalam masyarakat, maka peluang positivisasi jināyahhudūd secara maksimal di dalam Qanun Jinayat Aceh bukanlah hal yang mustahil dilakukan mengingat uaraian di atas semakin memperlihatkan ruang gerak syari'at yang kian leluasa.

Selain itu, peluang positivisasi tersebutjugadidukung dengan beberapa alasan, yaitu; alasan historis, gagasan syariat Islam merupakan tuntutan yang telah lama diperjuangkan oleh masyarakat Aceh. Bahkan jika ditarik sejarah yang lebih jauh, syariat islam telah dipraktekan sejak zaman Sultan Iskandar Muda, dan mencapai punak kejayaannya. Bahkan pada saat itu hukum rajam yang merupakan bagian jinayat sudah mulai dipraktekkan. Jadi tidak heran kenapa Aceh dijuluki serambi mekkah, karena syariat Islam telah begitu mengakar dalam kehidupan masyarakat Aceh. ${ }^{27}$ Alasan filosofis, masyarakat Aceh merupakan masyarakat yang memegang teguh nilai-nilai Islam dan menjadikan Islam sebagai landasan kehidupan. Masyarakat Aceh meyakini bahwa keberadaan dan kehidupannya di bumi ini tidak lepas dari aturan-aturan yang telah ditetapkan Allah swt, baik itu persoalan ibadah, muamalah, jinayat, dan lain-lain.

Alasan sosiologis, bagi masyarakat Aceh mempraktekkan nilai-nilai Islam dalam kehidupan merupakan suatu kewajiban. Hal demikian dapat dilihat dalam praktek-praktek adat didalam masyarakat, sehingga muncul adagium yang telah dikenal sejak dulu yakni;

${ }^{25}$ Muhammad Alkaf, Essai : Aceh Pasca 2005 (Ruang Politik Untuk Syari'at Islam). Makalah tersebut juga sudah didiskusikan lewat “Friday Forum Discussion" IAIN Langsa, pada tanggal 03-03-2018. Selengkapnya baca, http://padebooks.com/aceh-pasca-2005-ruang-politik-untuk-syariat-islam/

${ }^{26}$ Disampaikan oleh Muhammad Alkaf dalam "Friday Forum Discussion” IAIN Langsa, pada tanggal $03-$ 03-2018. Tonton Selengkapnya, https://www.youtube.com/watch?v=FVc3pked2hM

${ }^{27}$ Denys Lombard menjelaskan bahwa sejak zaman sultan Iskandar Muda (1607-1636) Islam telah menjadi gaya hidup masyarakat Aceh, dalam bidang pendidikan misalnya, orang tua wajib memberikan pendidikan agama Islam kepada anak saat berumur 7 tahun, seperti mengejarkan sembahyang, membiasakan beribadah, dan mengajarkan ilmu hitung dan bahasa Arab. Selengkapnya baca ; Denys Lombard, Kerajaan Aceh (Zaman Sultan Iskandar Muda, 1607-1636), (Jakarta : Kepustakaan Populer Gramedia, 2014), hal. 82-85. 
"hukom ngen adat, lagei zat ngen sifeut" 28 dan "islam ngen adat lagei qalam deungon daweut" ${ }^{29}$. Alasan yuridis, berdasarkan hasil uraian penulis pada bab sebelumnya, dapat dilihat bahwa dasar pelaksanaan hukum jinayat di Aceh mengacu pada UUD 1945 pasal 29 ayat (2) yang menyatakan bahwa negara menjamin kemerdekaan tiap-tiap penduduk untuk memeluk agamanya masingmasing dan beribadat menurut Agama dan kepercayaannya itu. Selanjutnya dikuatkan pula dengan UU No. 11 Tahun 2006 tentang Pemerintahan Aceh yang memberikan keluasan dalam hal melaksanakan syari'at Islam pada semua aspek.

Berdasarkan hasil uraian yang telah penulis jelaskan di atas mengenai luasnya ruang politik untuk syari'at Islam, maka peluang positivisasi jināyah hudūd secara menyeluruh di dalam qanun jinayat Aceh terbuka lebar. Karena semua gagasan yang menyangkutformalisasi syari'at Islam, sudah sangat diterima di dalam masyarakat Acehdan sadar untuk melaksanaknnya. hanya saja saat ini diperlukan dukungan dan kemauan yang kuat dari pihak eksekutif, legislatif, kaum cendikiawan, dan alim ulama guna mewujudkan hal tersebut, dengan mengacu kepada kebijakan politik hukum yang telah ditetapkan.

\section{Konsep Hudud yang Ideal}

Istilah hudūd berasal dari kata (had) yang berarti pembatas agar tidak tercampur, selain itu juga bisa berarti pencegahan pengekangan atau larangan. Secara istilah حدو (hudūd) adalah jenis hukuman yang telah ditetapkan oleh Allah SWT. untuk mencegah manusia agar tidak melakukan perbuatan yang

\footnotetext{
${ }^{28}$ Hukum (Islam) dan adat seperti zat dan sifat.

${ }^{29}$ Islam dan adat seperti pena dan tinta.

${ }^{30}$ Mustafa Hasan dan Beni Ahmad Saebani, Hukum Pidana Islam : Fiqh Jinayah, (Bandung: Pustaka Setia, 2013), hal. 46.
} lain. ${ }^{30}$

Abu Zahrah mendefinisikan hudūd sebagai hukuman yang telah ditentukan oleh Al-Quran dan Hadis Nabi terhadap kejahatankejahatan yang dengannya harus disegerakan atas hak Allah. Jadi dapat disimpulkan bahwa jināyah hudüd adalah perbuatan pidana yang telah ditentukan bentuk dan batas hukumannya dalam Al-Quran dan Hadis.

Hudūd sejak dahulu dan sekarang bukanlah sebuah konsep pidana yang muncul dalam ruang hampa, melainkan terus bergulat secara dinamis dengan perubahan sosial yang terjadi dalam masyarakat muslim. Boleh jadi penerapannya masa dulu dan masa sekarang (modern) bisa jadi sama, namun perbedaan konteks sosial, politik, ekonomi, budaya dan lain-lain bisa melahirkan pergeseran paradigma, pengembangan metode, hingga perubahan dampak pada masyarakat muslim. Misalnya salah satu perkembangan politik yang terjadi pada masa modern sekarang adalah tidak menyatunya masyarakat muslim dibawah kesatuan politik.

Mereka tersebar di beberapa negara dengan bentuk negara dan konsep politik yang beragam, dan hal tersebut menyebabkan jinayah hudud harus sesuai dengan konteks politik, sosial, dan ekonomi negara tersebut.

Konteks Aceh yang berada dalam wilayah yusridiksi Indonesia tentu saja bentuk hudūd harus disesuaikan dengan realitas hukum yang ada di Indonesia dan sesuai dengan konsep negara modern. Saat ini, dalam qanun jinayat Aceh pidana yang diancam dengan uqūbat hudūd hanya mencakup beberapa jenisjināyah saja yakni, khamr, qażaf, dan zina dengan satu macam bentuk hukuman berupa cambuk (dera). jenis 
hukuman hudūd seperti hukuman dera, amputasi, hukuman mati (qișạs), hukuman diyat (denda) belum tercantum di dalam qanun jinayat karena ada beberapa bentuk jarimah yang belum diatur.

Sebelum diundangkan melalui proses legislatif yang teratur dan demokratis, hukum pidana harus berusaha merangkum konsensus rakyat seluas mungkin. Secara khusus, aspirasi dan hak-hak minoritas etnik, agama, dan politik haruslah dihormati. Diktator mayoritas telah mengambil bentuk yang paling berbahaya ketika ia memaksakan kepentingannya dalam hukum pidana. Dari hasil penjelasan di atas mengenai kuatnya kedudukan qanun jinayat secara yuridis dan terbukanya ruang politik syari'at Islam di Aceh, memberikan peluang yang begitu lebar agar qanun jinayat Aceh saat ini memuat jinayah hudūd secara menyeluruh. Akan tetapi tetap saja harus ada penyesuaian-penyesuian dan tahapan-tahapandilakukan supaya bentuk pidana hudud yang diterapkan tidak mentah di masyarakat. karena secara logis hukum yang diterapkan sedikit demi sedikit akan mudah diserap dalam masyarakat.

Bentuk jināyah hudūd pun harus disesuaikan dalam konteks negara hukum modern dengan tidak menghilangkan norma ke-Acehan, agar hudūd tidak terkesan sebagai hukum yang out of the date dan dehumanis. Jadi dalam hal ini, Dinas Syari'at Islam harus sanggup mengkap ruh syari'at Islam yang akan dituangkan ke dalam jināyah hudūd nantinya.

Agar jināyahhudūd tidak terkesan leterjik (absolut), maka harus ada semacam dekontruksi terkait pemaknaan hudud sendiri. Pemahaman jināyahḥudūd memang harus diterjemahkan sebagai sebuah ijtihad ulama terdahulu, tapi pada perkembangan hukum modern tidak mustahil diinterpretasikan kembali sesuai dengan perkembangan tuntunan zaman dengan tidak merubah nilainilai dasar yang terkandung didalam syari'ah. ${ }^{31}$

Terkait jenis jināyah dan bentuk sanksi hudūd, juga harus dilakukan semacamdekontruksi agar dengan konsep negara modern dengan nuasnsa ke-Acehan. Saat ini qanun jinayat Aceh hanya memuat 3 (jenis) jināyah hudūd dengan satu macam bentuk sanksi. Sedangkan pada konsep hudūd yang penulis jelaskan pada sub-bab diatas terdapat 7 (tujuh) jenis jināyah hudūd dengan sanksi yang beragam. Jadi untuk menambah dan menyempurnakan ke jinayah hudud selanjutnya, perlu ada pengkajian yang lebih mendalam menganai berbagai hal.

Misalnya mengenai jināyah riddah (murtad), apakah perlu ditambahkan kedalam qanun jinayat Aceh. Mengingat daerah Aceh adalah daerah yang berada dalam wilayah yurisdksi Indonesia. Paling tidak, sedikit banyak jināyah hudūd juga harus mengikuti realitas hukum yang ada. Indonesia merupakan sebuah negara modern yang sangat menjunjung tinggi pluralisme dalam beragama, konseptualisasi riddah juga harus dipertanyakan kembali. Apakah perlu dituangkan ke dalam qanun jinayat Aceh. Mengingat hak beragama merupakan hak individu (privasi) yang tidak boleh dipaksakan pada setiap warga negara. setiap orang berhak memilih dan memeluk agamanya masing-masing bedasarkan konsep kebenaran yang ditemukan sendiri.

Riddah sendiri juga mengalami perbedaan konteks pada masa nabi dan sekarang, riddah yang terjadi pada masa Nabi diancam dengan hukuman mati karena pada saat itu riddah yang dilakukan terjadi pada musim perang, yakni sebagian dari tentra Islam melakukan desersi (penghianatan

${ }^{31}$ Makhrus Munajat, Dekonstruksi Hukum Pidana Islam, (Yogyakarta: Logung Pustaka, 2004), hal. 95. 
perang), maka Rasulullah memerintahkan ia untuk dibunuh. Itupun dengan upaya untuk menyadarkan si pelaku agar ia kembali kepada Islam. ${ }^{32}$ Beda halnya dengan konteks sekarang, Aceh merupakan wilayah damai dan bukan merupakan wilayah perang. Terlebih lagi hak beragama merupakan kebebasan setiap individu untuk menganut apa yang dia yakini. Jadi harus ada pengakajian kembali jika jinayah riddah ingin dicantum kedalam qanun jinayat Aceh.

Selanjutnya mengenai perspektif hukum potong tangan. Hukum potong tangan bisa diterapkan jika telah terpenuhi beberapa syarat, baik yang berkenaan dengan subyek, obyek maupun nasab barang curian. Ada halhal yang mana hukum potong tangan sendiri tidak bisa diterapkan, misalkan seperti orang tua yang mengambil harta anaknya dan pencurian yang dilakukan pada saat krisis pangan, terpaksa, dipaksa dan pencurian yang dilakukan hanya untuk memenuhi hajat perut pada hari itu saja. ${ }^{33}$

Fazlurrrahman mengatakan, dalam kasus pencurian perlu diterapkan teori gradasi. Artinya, pencuri yang baru pertama kali mencuri tidak harus dipotong tangan, melainkan hukum ta'zīr. Akan tetapi jika pencuriannya telah dilakukan lebih dari sekali dan sampai kepada nisab, maka dia dihukum potong tangan. ${ }^{34}$ Jadi pertimbangan seperti itu juga harus didepankan. Agar qanun jinayat tidak sekedar memuat pasal hudud yang maksimal, tapi juga melihat sisi subtansi dari hudūd itu sendiri.

Terakhir, harus ada kategori jināyah baru yang akan dmasukkan ke dalam qanun jinayat Aceh untuk merespon isu kekinian, sperti jināyah korupsi misalanya. Mengingat korupsi merupakan kejahatan yang sangat merugikan, bahkan boleh dikatakan kejahatan peradaban karena dapat memiskinkan dan menyengsarakan banyak manusia. Di Aceh sendiri kejahatan korupsi semakin meningkat, dan telah menempatkan Aceh sebagai provinsi termiskin se Sumatera. ${ }^{35}$ Karenanya jināyah korupsi patut menjadi pertimbangan untuk segara di masukkan kedalam qanun jinayat Aceh.

Beberapa negara seperti Brunai Darusalam, Malaysia, Arab Saudi, Iran, dan Pakistan, yang telah mempraktikkan jināyah hudūd memang memiliki tingkat keamanan yang tinggi, tapi di sisi lain masih banyak terdapat kekurangan mengenai kemaslahatan publik. ${ }^{36}$ Harusnya jināyah ḥudūd tidak hanya memberikan jaminan kemanan, tapi juga harus mampu membangkitkan kesejahtraan publik lain seperti sosial dan ekonomi. Hal ini yang harus diperhatikan di Aceh dalam rangka memuat jinayah hudud secara maksimal. Agar jināyah hudūd nantinya tidak terkesan dengan spirit penghukuman semata, tapi juga menghadirkan spirit pembangunan manusia.

Syeikh Yusuf Al-Qardhawi menyetujui jika Syariat islam dijadikan dasar negara, karena syari'at Islam pada hakikatnya

\footnotetext{
${ }^{32}$ Makhrus Munajat, Dekonstruksi Hukum Pidana Islam,.. hal. 126.

${ }^{33}$ Makhrus Munajat, Dekonstruksi Hukum Pidana Islam,...hal. 109.

${ }^{34}$ Fazlur Rahman, Metode dan Alternatif Neomodernisme Islam, (Bandung : Mizan, 1998), hal. 77.

${ }^{35}$ Selengkapnya baca, https://tirto.id/gurita-korupsi-di-bumi-syariat-aceh-cP9Q, diakses tanggal 3 juli 2019.

${ }^{36}$ Negara Arab Saudi, Iran, dan Pakistan memeperkenalkan hukum pidana Islam dalam bentuk terkodiikasi. Hukum pidana tersebut mencakup jarimah hudud, qisash, dan diyat. Akan tetapi dalam praktiknya hukum pidana Islam terlalu diterjemahkan secara ortodoks dan literlek, sehingga masih jauh dari prinsip-prinsip keadilan yang merupakan subtansi hukum pidana Islam itu sendiri. Misalnya seperti kasus TKI Tuti Tursilawati yang divonis dihukum pancung oleh pengadilan Arab Saudi karena membela dirinya dan kasus hukum rajam yang dialami Shadia di Pakistan karena dianggap telah berzina, padahal Shadia sendiri merupakan korban dari kesalahan proses administrasi pernikahan di pakistan. Selengkapnya, Dr. Nur Rafi'ah dan Imam Nahe'i, Kajian Tentang Hukum dan Penghukuman Dalam Islam: Konsep Ideal Hudud dan Parktiknya. hal. 186.
} 
memberikan kemaslahatan bagi manusia. Tapi dalam konteks negara hukum modern sekarang, tetap harus ada beberapa hal yang harus disesuaikan, misal seperti pada ranah jināyah hudūd dan qișāss. Menurut beliau,

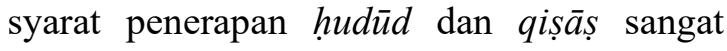
berat. Jadi tidak boleh diterapkan secara tergesa-gesa. Harus ada pertimbangan kondisi sosial dan ekonomi masyarakat. Misalnya tidak mungkin pidana hudud dilaksanakan dalam keadaan ekonomi masyarakat sedang tertekan dan sulit (tingkat kesejahtraan rendah). Pidana ḩudūd dan qiṣās juga tidak dapat dilaksanakan dalam keadaan pola pengajaran, pembelajaran, ideologi masyarakat, kebudayaan, dan lingkungan di sekitar jauh dari nilai-nilai keisalaman. Ada hal-hal penting dan utama yang harus diperhatikan sebleum jināyah ḥudūd dan qiṣāṣ dijalankan. ${ }^{37}$

Penerapan hudud secara literal yang banyak terjadi di negara modern saat ini menyimpan problem terkait dialektika antara teks dan realitas. Perubahan sosial yang terjadi secara terus menerus bisa melahirkan perkembang bentuk kejahatan sehingga sebuah kejahatan yang di suatu masa dipandang sebagai kejahatan kelas kakap, pada masa berikutnya menjadi kelas teri karena munculnya jenis kejahatan yang lebih kakap, misalnya pencurian dengan korupsi. Para ulama sesungguhnya telah menyediakan perangkat keilmuan untuk mengatasi hal ini melalui konsep ijtihad, baik Ijtihad Bayani (al-ijtihad min an-nushus), Ijtihad Qiyasi, dan maupun Ijtihad Istishlahi. ${ }^{38}$

Karena itu, dalam rangka memuat jināyah hudūd secara menyeluruh ke dalam qanun jinayat Aceh, uraian diatas sepatutnya dipertimbangkan. Agar qanun jinayat Aceh nantinya tidak terkesan sebagai qanun yang kuno (out of the date), tidak mengabaikan esensi kemanusiaan dan keadilan. Prinsip hudūd dalam qanun jinayat tidak boleh dirumuskan secara literlek (harfiah) dan terbatas pada apa yang disebutkan dalam AlQuran dan Hadis. Prinsip-prinsip dalam hudūd harus dikembangkan sedemikian rupa sehingga dapat menjangkau kejahatankejahatan baru yang lebih modern.

\section{E. KESIMPULAN}

Qanun Aceh No. 6 Tahun 2014 tentang Hukum Jinayat yang memuat 3 (tiga) jenis jinayah hudud merupakan qanun yang konstitusional. Qanun Jinayat Aceh memiliki tingkat konstitusionalitas yang kuat karena pelaksanaan qanun jinayat merupakan perintah langsung dari UU No. 11 Tahun 2006 tentang Pemerintahan Aceh, dan ditopang pula oleh beberapa undang-undang sebelumnya yakni, UU No. 44 Tahun 1999 tentang Penyelenggaraan Keistimewaan Provinsi Daerah Istimewa Aceh dan UU No. 18 Tahun 2001 mengenai otonomi khusus bagi provinsi Aceh.

Berdasarkan teori penafsiran konstitusi yang penulis gunakan untuk mengelaborasi pasal-pasal HAM, maka jarimah hudūd di dalam qanun jinayat Aceh dengan jenis sanksi cambuk merupakan pelaksanaan dari nilainilai HAM itu sendiri. UUD 1945 pasal 29 ayat (2) menyebutkan bahwa; "Negara menjamin kemerdekaan tiap-tiap penduduk untuk memeluk agamanya masing-masing dan untuk beribadat menurut agamanya dan kepercayaannya itu". Berdasarkan tingkat konstitusonal yang sangat kuat, maka sangat memungkinkn qanun jinayat dapat memuat jarimah hudud secara menyeluruh termasuk memasukkan hukuman mati didalamnya. Akan tetapi penyempurnaan ke tahap jarimah

${ }^{37}$ Kajian Tentang Hukum dan Penghukuman Dalam Islam: Konsep Ideal Hudud dan Parktiknya. hal. 198.

${ }^{38}$ Kajian Tentang Hukum dan Penghukuman Dalam Islam: Konsep Ideal Hudud dan Parktiknya. hal. 199. 
hudud tersebut perlu disesuaikan dengan konteks zaman modern dalam kaedah negara bangsa seperti sekarang, agar nantinya qanun jinayat tidak terkesan kuno dan out of the date

\section{DAFTAR PUSTAKA}

\section{Undang-Undang:}

UUD 1945.

Undang-Undang Nomor. 11 Tahun 2006.

Undang-Undang Nomor 44 Tahun 1999.

Undang-undang Nomor 18 Tahun 200.

Undang-Undang Nomor. 39 Tahun 1999

\section{Buku:}

Abbas, Syahrizal. (2015). Maqasidh AlSyariah Dalam Hukum Jinayah Aceh, Banda Aceh: Dinas Syari'at Islam Aceh.

Asshiddiqie, Jimly. (2011) Konstitusi dan Konstitusionalisme Indonesia, Jakarta: Sinar Grafika.

Fatimah, Siti. (2005).Praktik Judicial Review di Indonesia: Sebuah Pengantar, Yogyakarta: Pilar Media.

Hasan, Mustafa dan Saebani, Beni Ahmad (2013) Hukum Pidana Islam: Fiqh Jinayah, Bandung: Pustaka Setia.

Isa, Abdul Gani. (2013) FormalisasiSyari'at Islam di Aceh (PendekatanAdat, Budaya, danHukum), Banda Aceh :Yayasan Pena.

Lombard, Denys. (2014). Kerajaan Aceh (Zaman Sultan Iskandar Muda, 16071636), Jakarta: Kepustakaan Populer Gramedia.

Munajat, Makhrus. (2004). Dekonstruksi Hukum Pidana Islam, Yogyakarta: Logung Pustaka.

Munajat, Makhrus. (2008). Hukum Pidana Islam di Indonesia, Yogyakarta: Sukses Offset.

Noviandy (ed.). (2018). Perempuan dan Hak Asasi Manusia; Narasi Agama dalam
Imajinasi Negara Bangsa di Aceh, Malang: PUSAM UMM.

Rafi'ah, Nur dan Nahe'I, Imam. (2016) Kajian Tentang Hukum dan Penghukuman Dalam Islam: Konsep Ideal Hudud dan Parktiknya, Jakarta: Komnas Perempuan.

Rahman, Fazlur. (1998) Metode dan Alternatif Neomodernisme Islam, Bandung: Mizan.

Tesis / Disertasi:

Akbar, Khairil. (2017)Relevansi Prinsip Pemidanaan Islam Terhadap Sila Ketuhanan Yang Maha Esa (Studi Terhadap Qanun Aceh Nomor 6 Tahun 2014 Tentang Hukum Jinayah), Yogyakarta : Pasca Sarjana UII.

Muzakkir. (2017). Adopsi dan Aplikasi Hukum Jinayah Melalui Qanun Aceh (Studi Terhadap Qanun Nomor 6 Tahun 2014), Medan: Pasca Sarjana USU.

\section{Jurnal:}

Danial. (2012). Qanun Jinayah Aceh dan Perlindungan HAM, Jurnal Kajian Hukum Islam Al-Manahij, Vol VI No.1.

Husni Mubarak A. Latief, "Disonansi Qanun Syari'at Islam Dalam Bingkai Konstitusi Hukum Indonesia : Aceh Sebagai Studi Kasus", Annual International Conference on Islamic Studies (AICIS XII).

Sodikin. (2013). Hukum dan Kebebasan Beragama, Jurnal Cita Hukum, Vol. 1 No. 2.

\section{Website:}

Alkaf, Muhammad. Essai: Aceh Pasca 2005 (Ruang Politik Untuk Syari'at Islam). Makalah tersebut juga sudah didiskusikan lewat "Friday Forum Discussion" IAIN Langsa, pada tanggal 03-03-2018. Selengkapnya baca, http://padebooks.com/aceh-pasca2005-ruang-politik-untuk-syariat-islam/ 
Friday Forum Discussion IAIN Langsa, pada tanggal

2018.https://www.youtube.com/watch? $\mathrm{v}=\mathrm{FVc} 3$ pked $2 \mathrm{hM}$

http://Aceh.tribunnews.com/2018/03/16/wac ana-hukuman-pancung-di-Aceh-prodan-kontra-warganet-hingga-ditentangpemerintah-pusat

https://aceh.tribunnews.com/2017/11/01/saye mbara-himne-aceh-diprotes, https://www.merdeka.com/peristiwa/m ahasiswa-aceh-rakyat-butuhkesejahteraan-bukan-walinanggroe.html, http://www.tribunnews.com/topic/kontr oversi-bendera-aceh https://aceh.tribunnews.com/2017/11/01/saye mbara-himne-aceh-diprotes, https:/www.merdeka.com/peristiwa/m ahasiswa-aceh-rakyat-butuhkesejahteraan-bukan-walinanggroe.html, http://www.tribunnews.com/topic/kontr oversi-bendera-aceh

https://nasional.kompas.com/read/2016/10/23 /23340501/setahun.diberlakukan.qanun .jināyah.Aceh.diminta.dikaji.ulang

https://www.hukumonline.com/berita/baca/lt 59e5b3502e8dd/melihat-kembalitempat-hukum-pidana-islam-dalamsistem-hukum-nasional 